\title{
Rights to restitution for child victim of criminal act under government regulation number 43 year 2017
}

\author{
Azmiati Zuliah* and Madiasa Ablisar \\ Doctoral Program in Law, Universitas Sumatera Utara, Medan, Sumatera Utara, Indonesia
}

\begin{abstract}
The criminal act against children is a gross violation of human rights. The criminal act committed by the offenderis intolerable because it can affect their survival as well as growth and development. Therefore, the victim deserves legal protection. Restitution is one of forms of protection and fulfillment of the rights of the child to compensate any damages. So far, child victim of criminal act suffers not only material loss (countable) but also immaterial loss (uncountable) such as shame, loss of self-esteem, depression and/or traumatic anxiety.It is the fact that so far the rights of child victims to restitution are very often violated. Therefore, the child victim and his or her family feel that they do not given justice. It is hoped Government Regulation Number 43 Year 2017 will be able to give legal certainty to the victim to ensure that he or she can enjoy his or her rights to restitution for any loss he or she suffers as stipulated in Law Number 35 Year 2014 on the Revision of Law Number 23 Year 2002 on Child Protection. This research uses theory of justice as grand theory, law enforcement as middle range theory and theory of victimology as applied theory.
\end{abstract}

\section{Introduction}

Law Number 35 Year 2014 on the Revision of Law Number 23 Year 2002 on Child Protection gives special protection to child victim of criminal act. The special protection is given to children in conflict with the law, especially child victim of economic and/or sexual exploitation, pornography, kidnapping, sale, and/or trafficking, physical and/or psychological abuse, and sexual crimes, for harm or loss he or she suffers in the form of a compensation from the offender or his or her family, especially if the offender is a child as a result of the committed criminal act. [1]

Every child victim is entitled to file to court his or her right to claim for restitution imposed on the offender.[2] Article 71 D of Law Number 35 Year 2014 on the Revision of Law Number 23 Year 2002 on Child Protection stipulates that (1) Every child victim as referred to in Article 59 paragraph (2) point $b$, point $d$, point $f$, point $h$, point $\mathrm{i}$, and point $\mathrm{j}$ is entitled to file to court his or her right to claim for restitution imposed onthe offender; (2)

\footnotetext{
*Corresponding author: emi_zuliah@yahoo.com
} 
further provisions on the implementation of restitution as referred to in paragraph (1) shall be regulated by a government regulation.

In the elucidations of article above, "restitution" shall mean the payment of compensation imposed on the offender based on court ruling having permanent legal force for the material and/or immaterial damages suffered by victims or their beneficiaries. [3]. Especially for children in conflict with the law, the one who is entitled to receive restitution is the child victim.

Unfortunately, up to now there are still various problems in the payment of restitution at police, judiciary and court levels. From victimology point of view, restitution aims to minimize victim's sufferings by claiming the offender be held responsible for physical or morallosses or death suffered by the victim.

This principle affirms that victim recovery must covered various aspects raised by the criminal act. The victim and his or her family must receive just and proper compensation from the guilt or a third party that is held responsible for the criminal act. The compensation will include the return ofproperty or payment of any damage or loss suffered by the victim, payment of costs arising as a result of death, provision of services and rights to recovery. [4]

\section{Formulation of the Problem}

The problem of this research are: how is restitution regulated in Government Regulation Number 43 Year 2017 on payment of restitution to child victim of criminal act and also what are the roles of law enforcers in the implementation of restitution and weaknesses of the implementation of restitution.

\section{Research methods}

This research is a juridical normative research which is qualitative in nature. The juridical normative research aims to analyze concepts of laws and regulations which are closely related to the topic of the research.

The primary data in the research was collected through field research. Meanwhile, the secondary data was collected through documentary research. The documentary research aims to find various concepts, theories, principles, doctrines and various documents which are related to the topic of the research.

\section{Discussions}

\subsection{Regulations on Restitution in Government Regulation Number 43 Year 2017}

On 17 October 2017, the Government of Indonesia made a regulation on restitution for child victim of criminal act through Government Regulation Number 43 Year 2017. The making of this Government Regulation is a mandate of Article 71 D paragraph (2) of Law Number 35 Year 2014 on the Revision of Law Number 23 Year 2002 on Child Protection which stipulates that every child victim as referred to in Article 59 paragraph (2) point b, point $d$, point $f$, point $h$, point $i$, and point $j$ is entitled to file to court his or her right to claim for restitution imposed on the offender. [5]

The victim and his or her family must receive just and proper compensation from the guilt or a third party that is held responsible for the criminal act. The compensation will 
include the return of property or payment of any damage or loss suffered by the victim, payment of costs arising as a result of death, provision of services and rights to recovery.[6]

In principle, rule of law which regulates restitution in Government Regulation Number 43 Year 2017 defines restitution as the payment of compensation imposed on the offender based on court ruling having permanent legal force for the material and/or immaterial damages suffered by victims or their beneficiaries.

Under Government Regulation Number 43 Year 2017, claim for restitution can be submitted by the victim's parents or guardian; or victim's beneficiary; or someone given an authority by victim's parents, guardian, or beneficiary. Claim for restitution can also be submitted by an institution in case the victim is the offender of the criminal act. Claim for restitution can be submitted to investigator during investigation phase or to public prosecutor during prosecution phase. It also can be submitted through the Witness and Victim Protection Agency (Lembaga Perlindungan Saksi dan Korban - LPSK) in accordance with provisions contained in the applicable laws and regulations.

Government Regulation Number 43 Year 2017 also regulates the authority of investigator and public prosecutor to give information on rights to restitution to the victim and regulates the technical matters of the implementation of restitution by judge. In addition, it gives authority to the Witness and Victim Protection Agency to assess loss suffered by the victim. [7]

\subsection{The Roles of Law Enforcers in the Implementation of Restitution}

Actually, there are a number of parties that play important roles in the implementation of restitution to ensure that the rights of victim of criminal act to restitution can be fulfilled. Submission of claim for restitution for victim of criminal act and filing of the criminal case must be done by law enforcers. So, they play vital roles in restitution. [8]

Below are law enforcers that play vital roles in restitution.

\subsubsection{The Roles of Investigator}

Claim for restitution can be submitted when the victim reports his or her case to local police and this delt with by investigator at the same time with the handling of his or her criminal case. So, the roles of the investigator start when the victim report the criminal case. The investigator must immediately inform the victim on how he or she can receive compensation from the offender. For example, the victim must collect evidences that can be used as a basis to receive restitution such as proof of payments for medical service, etc. These evidences must be enclosed to or included in his or her case reporting documents. [9]

\subsubsection{The Roles of Public Prosecutor}

Public prosecutor can play a role by informing the victim about his or her right to claim for restitution. Then, the public prosecutor inform about losses suffered by the victim and his or her prosecution. [10]

It is particularly important for the public prosecutor to inform the victim about his or her rights because the victim, who is usually a community member, is not familiar with legal proceeding and does not know his or her rights as a victim. So, sharing this information to the victim will be very helpful for him or her. In addition to having done his or her legal responsibility, the public prosecutor also has helped the victim, as a justice seeker, enjoy his or her rights to restitution.

In his or her prosecution, the public prosecutor has to submit a request for restitution based on evidence brought to the court and inform the amount of the requested restitution to 
the Witness and Victim Protection Agency after the request or the complete document is submitted.

\subsubsection{The Roles of Judge}

Judge plays a vital role in considerating the amount of restitution for victim's material and immaterial losses. It is his or her obligation to include it in the dictum/court decision, make just decision and impose severe punishment on the offender in accordance with the severence of his or her criminal act as well as give compensation for victim's material and immaterial damages and losses.

Therefore, it is hoped judge will make court decision by considering not only legal justice but also moral justice to get precise justice because the defendant/the offender also has a right to justice. It must be noted that communities have to get justice from judge's decision. This may take the form of sense of safety, peace of mind and relief because the judge's decision is acceptable and just.

Judge's decision is the end of a case handled by judge. Therefore, judge has to consider various aspects in decision making such as the importance of carefulness, avoidance to possible carelessness about formal and material aspects of the case and technical capability in decision making.

It is hoped that judge also will get moral satisfiction when his or her decision is used as a reference for similar or same cases by law experts and legal practitioners and when his or her decision is upheld and not dismissed by a higher court. [11]

\subsection{Challenges in the Implementation of Government Regulation Number $\mathbf{4 3}$ Year 2017 on Restitution}

There are still various legal issues after the issuance of Government Regulation Number 43 Year 2017 as mandated by Law Number 35 Year 2014 on the Revision of Law Number 23 Year 2002 on Child Protection.

This is because the Government Regulation does not explicitly explain sanction for offender who is unable to pay the restitution and how the prosecutor shall seize the assets of the convicted offender.

This provision should be amended to be adjusted to losses suffered by the victim and supervision of the offender's assets. This aims to prevent the convicted offender from not paying the restitution. Unlike the Government Regulation, Law on the Eradication of the Criminal Act of Trafficking in Persons contains provisions on asset seizure and imposement of a subsidiary criminal saction if the offender is unable to pay the restitution although, in fact, a victim of the criminal act of trafficking in person rarely suffers from financial loss.

Other obstacle in the implementation of Government Regulation Number 43 Year 2017 is that victim and his or her family do not know how to submit claim for restitution. This process actually should be facilitated by police, prosecutor and Witness and Victim Protection Agency.

Procedure to claim for restitution is complicated and victim is usually asked to trace or search for the offender's assets, both those which are still in the name of the offender and those which have been converted to other parties as an effort to make their ownership unclear or avoid them from possible legal measure by law enforcers.

It is the Witness and Victim Protection Agency that can determine whether or not a criminal act case deserves restitution. The problem is that the agency is located in Jakarta and it cannot reach all cases throughout Indonesia. 
Other problem is the mechanism and procedure for submitting claim for and implementing restitution because the Witness and Victim Protection Agency is not a part of criminal justice system and it is not a law enforcement agency which has executorial authority. Additionally, it is difficult for the Witness and Victim Protection Agency to prove the material lose suffered by the victim because he or she does not have any proof. [12]

However, it is a fact that victim has spent his or her money for medical service, lost property or spent some money during the legal proceeding. Unfortunately, he or she does not have any written proof of these costs.

There are also some obstacles in the implementation of restitution by during law enforcement. At investigation phase, for example, police investigator very often does not include restitution in the police investigation report (Berita Acara Pemeriksaan - BAP) because not all police officers understand restitution well. It is also quite difficult to collect relevant evidence to enable the victim to submit a claim for restitution for any material or immaterial loss he or she has suffered. [13]

At prosecution level, prosecutor very often does not include restitution in his or her prosecution because there is no mechanism or technical procedure for submitting claim for restitution when the prosecutor submits his or her prosecution. Additionally, it is difficult to assess immaterial loss suffered by the victim. Laws in Indonesia do not clearly state or determine the amount of restitution which can be claimed to the victim through the court. In addition, it is difficult to assess or calculate immaterial loss suffered by the victim. [14]

At conviction level, it is difficult for the judge to decide whether or not the offender has to pay restitution to the victim because the offender has neither mobile asset or immobile asset. In addition, under the applicable laws, a subsidiary punishment can be imposed on the offender if he or she is unable to pay the restitution to the victim.

Therefore, we need to advocate law enforcers to ensure that they will facilitate victim to submit claim for restitution. Besides that, the Government Regulation gives a strong mandate to the Witness and Victim Protection Agency to help the victim assess any damage or loss he or she suffers. This mandate must be done by the agency maximally without condition.

\section{Conclusions}

\subsection{Summary}

Rights to restitution for child victim of criminal act are regulated in various laws and regulations in Indonesia. One of them is Law Number 35 Year 2014 on the Revision of Law Number 23 Year 2002 on Child Protection. In practice, the implementation of restitution is regulated through Government Regulation Number 43 Year 2017 on the Implementation of Restitution for Child Victim of Criminal Act.

Under the government regulation, the provision of restitution to child victim of criminal act aims to help the victim pay recovery costs and get justice although there are still various obstacles in its implementation.

The roles of law enforcers in restitution are greatly dependent on their understanding of the implementation of the applicable laws at investigation, prosecution and conviction levels. They also have to inform child victim about their rights as a victim of criminal act, especially his or her rights to restitution, to ensure that he or she can enjoy these rights.

There are still various obstacles in the provision of restitution to child victim of criminal act. These obstacles are caused by not only law enforcers' lack of understanding of the applicable laws and regulations, ambiguous legal sanction that can be imposed on the 
offender if he or she refuses or is unable to pay the restitution but also complicated procedure for submitting claim for restitution and difficulties to prove the material and immaterial losses suffered by the victim.

\subsection{Recommendations}

Government has to ensure that victim of criminal act can enjoy his or her rights by better formulating draft of the Indonesian Criminal Code.

Request for restitution must be filed at the time the victim reports his or her case to police and it is handled by investigator together with the case handling. The investigator informs the victim his or her rights to request for restitution and includes details of loss suffered by the victim in the investigation report. Then, the investigator submits the report to public prosecutor for further assessment or study. If the public prosecutor finds that the prosecutor does not include details of loss suffered by the victim, he or she will advise the investigator to revise the report. The public prosecutor has to consult the victim to ensure that he or she has proof of his or her loss which is prepared or legalized by relevant authority. After that, public prosecutor who is appointed to handle the case has to ask the victim to file his or her request for restitution which will be submitted to the public prosecutor together with the prosecution. This is done to fill gaps and address inclarity in the criminal law procedure in Indonesia.

\section{References}

1. Elucidations on Government Regulation Number 43 Year 2017 on the Implementation of Restitution for Child Victim of Criminal Act

2. Law Number 35 Year 2014 on the Revision of Law Number 23 Year 2002 on Child Protection, Article 71D paragraph 1

3. Elucidations on Government Regulation Number 43 Year 2017. Op.cit

4. Muliyawan, Artikel ,paradigma baru hukum perlindungan anak, pasca perubahan undang-undang perlindungan anak, (PN Palopo, 2015)

5. Elucidations on Government Regulation Number 43 Year 2017. Op.cit

6. Y.P Sibuea,Harris, Persoalan restitusi terhadap anak korban tindak pidana, majalah info singkat, Vol No 21/Puslit/November/2017.

7. Supriyadi Widodo Eddyono, et.al, "Inputs for Revision of Law Number 13 Year on Witness and Victim Protection" p.16( Koalisi Perlindungan Saksi dan Korban,Jakarta, 2006)

8. Article 9 of Government Regulation Number 43 Year 2017

9. Article 14 of Government Regulation Number 43 Year 2017

10. Sujoko, The Implementation of Claim for Compensation in Article 98 of the Criminal Code for the Criminal Act of Rape in Semarang Territory, p. 170(A Thesis of Magister Program of Faculty of Law of Diponegoro University, Semarang, 2008)

11. http://www.hukumonline.com/berita/baca/lt59eef5e356c54/ini-poin-poin-pppelaksanaan-restitusi-bagi-anak-korban-tindak-pidana

12. Muhadar, E. Abdullah, dan H. Thamrin, Perlindungan saksi \& korban dalam sistem peradilan pidana, p.20 (Putra Media Nusantara, Surabaya 2009)

13. http://sp.beritasatu.com/home/lpsk-pidana-perdagangan-orang-harus-perhitungkanrestitusi $/ 84254$ 
14. Marlina, A. Zuliah, , Hak Restitusi Terhadap Korban Tindak Pidana Perdagangan Orang, p.89 (PT Refika Aditama, Bandung 2015) 